\title{
Bacterial Contamination on Beef Sold at Selected Wet Markets in Selangor and Kuala Lumpur
}

\author{
Siti Shahara Zulfakar ${ }^{1}$, Norfarisya Baharudin ${ }^{1} \&$ Nur Faizah Abu Bakar ${ }^{2}$ \\ ${ }^{1}$ Environmental Health and Industrial Safety Program, School of Diagnostic and Applied Health Sciences, Faculty \\ of Health Sciences, Universiti Kebangsaan Malaysia, Kuala Lumpur, Malaysia \\ ${ }^{2}$ Dean's Office, Faculty of Health Sciences, Universiti Kebangsaan Malaysia, Kuala Lumpur, Malaysia \\ Correspondence: Siti Shahara Zulfakar, Environmental Health and Industrial Safety Program, School of \\ Diagnostic and Applied Health Sciences, Faculty of Health Sciences, Universiti Kebangsaan Malaysia, Kuala \\ Lumpur 50300, Malaysia. Tel: 60-3989-7237. Email: sitishahara.zulfakar@ukm.edu.my
}

Received: October 3, 2017

Accepted: December 11, 2017

Online Published: December 31, 2017

doi:10.5539/jas.v9n13p89

URL: https://doi.org/10.5539/jas.v9n13p89

\begin{abstract}
Beef is one of the essential sources of protein in human diet. But retail beef are easily contaminated with pathogenic bacteria and can cause foodborne disease. To determine the bacterial contamination, 45 samples of retail beef including imported beef $(n=24)$ and local beef $(n=21)$ were collected from selected wet markets at every district in Selangor. Samples were analyzed for total viable counts (TVC), Escherichia coli, Enterobacteriaceae and the incidence of pathogenic bacteria which are Salmonella spp. and E. coli O157:H7. Overall results showed that all beef samples $(n=45)$ were positive for TVC and Enterobacteriaceae at an average reading of (mean $\pm \mathrm{SD}$ ) $7.05 \pm 0.78 \mathrm{log} \mathrm{CFU} / \mathrm{g}$ and $5.05 \pm 0.87 \mathrm{log} \mathrm{CFU} / \mathrm{g}$, respectively. Only $53.3 \%$ of the total samples were contaminated with E. coli $(4.22 \pm 0.60 \log \mathrm{CFU} / \mathrm{g})$ whereas only $24.4 \%$ of total samples were found to be positive with Salmonella spp. All bacterial count readings fall under the marginal category based on the international standards. There were no significant differences $(p>0.05)$ in microbial counts between the local and imported beef samples for all parameters. Among the E. coli isolates detected from the beef samples, 3 isolates were identified as E. coli O157:H7. In conclusion, meat safety level for the retail beef sold at wet markets in Selangor and Kuala Lumpur is low and requires more attention from the authorities to ensure its microbiological safety for consumers.
\end{abstract}

Keywords: bacterial contamination, wet market, retail beef

\section{Introduction}

\subsection{Food-Borne Illness}

Food-borne illness caused by the food-borne bacteria had been the crucial global health problems. It could increase the medical cost of individuals and possibly death (Fratamico, 2005). Numerous cases of raw meat as one of the main sources of food borne illness has been reported (Bhandare et al., 2007). E. coli O157, Salmonella spp., and Campylobacter spp., were the most dominant pathogens involved and were often present in fresh meat and poultry (Todd, 1997).

\subsection{Beef Industry}

Beef is one of the major foods of animal origin and has become a part of regular diet for Malaysians. To fulfill the demands of beef products in Malaysia, imported beef supply were imported from other countries such India, Australia, New Zealand, Uruguay, Brazil and Argentina (Ministry of Agriculture and Agro-Based Industry, 2014). This beef products, local and imported are readily sold in wet markets and also supermarkets in Malaysia. However, local beef supply is fairly limited as compared to imported beef as the later are much cheaper and dominates the market (Serin et al., 2008). In Malaysia, most consumers prefer to buy meat from the wet markets because they claimed that all meat at the wet market was fresher than frozen imported meats and was sent directly to the wet markets from the abattoir right after it was being slaughtered (Anjum et al., 2004; Chamhuri \& Batt, 2009). 


\subsection{Beef Contamination}

Beef available at retail outlets have gone through a long chain process before it is ready at the retails (Ahmad et al., 2013). The contamination risks were increase during the slaughter and processing of the carcasses (Chapmen 1997). Contaminations also can be compounded during transportation, storage and handling of meat by retailers (Ahmad et al., 2013). This study aimed to assess the contamination of aerobic bacteria, Enterobacteriaceae, $E$. coli and Salmonella spp. on local and imported beef from selected wet markets located around Selangor and Kuala Lumpur area.

\section{Material and Methods}

\subsection{Sample Collection and Preparation}

45 samples of beef were collected at a randomly selected wet market in every nine districts of Selangor. Number of beef samples was varied between the wet markets according to the number of vendors available in each wet markets. From the total samples, 21 samples were local beef while 24 samples were imported beef. 100 grams of beef were bought from each beef vendors at the selected wet markets. The samples were then brought to the lab in a cold box and stored at $4{ }^{\circ} \mathrm{C}$. All samples were analyzed in within $48 \mathrm{hrs}$ after collection.

Twenty-five grams of each collected beef samples were weighed and transferred to a sterile bag containing 225 $\mathrm{ml}$ of sterilized $0.1 \%(\mathrm{v} / \mathrm{v})$ buffered peptone water (Merck, Germany). Samples were then homogenized using a stomacher (MiniMix 100PCC Lab Blender, Interscience France) for 2 mins. Ten $\mathrm{ml}$ of the homogenized samples were taken out to be used for enrichment steps for detection of Salmonella spp. and the remaining samples were used for detection and enumeration of total viable count (TVC), Enterobacteriaceae and E. coli. A 10-fold series dilution were performed on the homogenized samples.

\subsection{Detection and Enumeration of Total Viable Count (TVC), Enterobacteriaceae and E. coli}

Spread plate technique was used for the enumeration of TVC, Enterobacteriaceae and E. coli on Plate Count Agar (PCA) (Merck, Germany), Violet Red Bile Dextrose (VRBD) (Merck, Germany) agar and Eosin Methylene Blue (EMB) (Merck, Germany) agar respectively. A $0.1 \mathrm{ml}$ aliquot from appropriate dilutions was plated on each agar in triplicates. The plated agars were then incubated aerobically at $37^{\circ} \mathrm{C}$ for 24 hours. Colony forming unit $\left(\mathrm{CFU} / \mathrm{g}\right.$ ) were counted and converted to $\log _{10} \mathrm{CFU} / \mathrm{g}$. Further biochemical tests (Indole, methyl red, Voges-Proskauer and citrate test) were conducted for confirmation of $E$. coli colonies detected on the EMB agar.

\subsection{Detection of Salmonella spp.}

Pre-enrichment of the homogenized sample was done by incubating $10 \mathrm{ml}$ of the homogenized sample at $37{ }^{\circ} \mathrm{C}$ for $20 \mathrm{hrs}$. A $0.1 \mathrm{ml}$ aliquot of the pre-enriched samples was then transferred to $10 \mathrm{ml}$ Rappaport-Vassiliadis soy broth (Merck, Germany) and vortex thoroughly before incubated at $41.5^{\circ} \mathrm{C}$ for 24 hours for selective enrichment process. After incubation, a loopfull of the enriched broth was then streaked onto Xylose Lysine Deoxycholate (XLD) agar (Merck, Germany) and incubated at $37^{\circ} \mathrm{C}$ for 24 hours. Detection of Salmonella sp. was recorded by the presence of red colonies with black centers. Further biochemical tests (Indole, methyl red, Voges-Proskauer, citrate and Triple Sugar Iron) were conducted for confirmation of Salmonella sp. colonies detected on the XLD agar.

\subsection{Detection of E. coli O157:H7}

Confirmed E. coli isolates from the biochemical test were further tested to determine the presence of $E$. coli O157:H7. A single colony of the E. coli isolates was grown overnight on Tryptic Soy Agar (Merck, Germany) and then streaked onto Cefixime-Tellurite-Sorbitol MacConkey agar in triplicates. The agar was then incubated at $37^{\circ} \mathrm{C}$ for 24 hours. Presence of E. coli $\mathrm{O} 157: \mathrm{H} 7$ was confirmed with the growth of colourless colonies on the agar.

\subsection{Statistical Analysis}

All results for enumeration of bacterial concentrations were presented as mean \pm standard deviation (SD). Differences in level of bacterial contamination between local and imported beef were determined using Independent Student's T-test. All statistical tests were performed using SPSS version 22. Results were considered significant at $\mathrm{p}<0.05$ unless otherwise stated.

\section{Results}

\subsection{Contamination of Total Viable Counts (TVC), Enterobacteriaceae and E. coli}

The bacterial loads of total viable counts (TVC), Enterobacteriaceae and E. coli of the beef sold at selected wet markets in Selangor and Kuala Lumpur were summarized in Table 1. Overall results showed that all beef 
samples $(\mathrm{n}=45)$ were positive for TVC and Enterobacteriaceae at an average reading of (mean \pm SD) $\log$ $7.05 \pm 0.78 \mathrm{CFU} / \mathrm{g}$ and $\log 5.05 \pm 0.87 \mathrm{CFU} / \mathrm{g}$, respectively. Only $53.3 \%$ of the total samples were contaminated with E. coli $(\log 4.22 \pm 0.60 \mathrm{CFU} / \mathrm{g})$ whereas only $24.4 \%$ of total samples were found to be positive with Salmonella spp.

Table 1. Microbial load of Total Viable Count, Enterobacteriaceae and E. coli on local and imported beef samples sold at wet markets in Selangor and Kuala Lumpur

\begin{tabular}{|c|c|c|c|c|c|c|}
\hline \multirow{3}{*}{ Beef samples } & \multicolumn{6}{|c|}{ Microorganisms detected on beef samples } \\
\hline & \multicolumn{2}{|c|}{ Total Viable Count } & \multicolumn{2}{|c|}{ Enterobacteriaceae } & \multicolumn{2}{|c|}{ E. coli } \\
\hline & No. $(\%)^{1}$ & $\mathrm{Mean}^{2} \pm \mathrm{SD}$ & No. $(\%)$ & Mean \pm SD & No. $(\%)$ & Mean \pm SD \\
\hline Local beef & $21(100)$ & $7.04 \pm 0.78$ & $21(100)$ & $5.03 \pm 0.84$ & $10(47.6)$ & $4.29 \pm 0.53$ \\
\hline Imported beef & $24(100)$ & $7.06 \pm 0.78$ & $24(100)$ & $5.06 \pm 0.92$ & $14(58.3)$ & $4.17 \pm 0.766$ \\
\hline Total $(N=45)$ & $45(100)$ & $7.05 \pm 0.78$ & $45(100)$ & $5.05 \pm 0.87$ & $24(53.3)$ & $4.22 \pm 0.60$ \\
\hline
\end{tabular}

Note. ${ }^{1}$ Number and percentage of positive samples; ${ }^{2}$ Mean bacterial counts expressed in $\log$ CFU/g.

Based on the data (Table 1), all of the bacterial load readings are higher than the limits stated in the International Guidelines for raw beef (Table 2). The average TVC counts for both local $(7.04 \pm 0.78 \log$ CFU/g) and imported $(7.06 \pm 0.78 \log \mathrm{CFU} / \mathrm{g})$ beef have exceeded the acceptable limit according to the Australian guideline (5 log $\mathrm{CFU} / \mathrm{g}$ ). Similar observations were also made on the average reading of Enterobacteriaceae for both local $(5.03 \pm 0.84 \log \mathrm{CFU} / \mathrm{g})$ and imported beef $(5.06 \pm 0.92 \log \mathrm{CFU} / \mathrm{g})$ samples which falls under the marginal category based on the EU guideline. The average counts of E. coli for both type of samples were also have exceeded the acceptable limit by the Australian Standards (local beef $=4.29 \pm 0.53 \mathrm{log} \mathrm{CFU} / \mathrm{g}$; imported beef $=$ $4.17 \pm 0.766 \log \mathrm{CFU} / \mathrm{g})$. From these E. coli positive samples, three isolates have been identified as $E$. coli O157:H7.

Table 2. Classification of bacterial counts based on International Standards

\begin{tabular}{|c|c|c|c|c|c|c|c|c|}
\hline \multirow{2}{*}{ Category } & \multicolumn{2}{|c|}{ Total Viable Count } & \multicolumn{2}{|c|}{ Enterobacteriaceae } & \multicolumn{2}{|c|}{ E. coli } & \multicolumn{2}{|c|}{ Salmonella spp.** } \\
\hline & $\mathrm{AUS}^{\mathrm{a}}$ & $\mathrm{EU}^{\mathrm{b}}$ & AUS & EU & AUS & EU & AUS & $\overline{E U}$ \\
\hline Excellent & $<3.0^{*}$ & $<2.8$ & - & $<1.8$ & Absent & - & Absent & $<2$ samples \\
\hline Good & $3.0-4.0$ & - & - & - & $0.0-1.0$ & - & - & \\
\hline Acceptable & -5.0 & - & - & - & $1.0-2.0$ & - & - & \\
\hline Marginal & $>5.0$ & $>4.3$ & - & $>2.8$ & $2.0-3.0$ & - & Present & $>2$ samples \\
\hline
\end{tabular}

Note. ${ }^{\mathrm{a}}$ Australian Standards (2002); ${ }^{\mathrm{b}}$ European Union (2002); - not stated in the guideline; ${ }^{*}$ unit expressed in $\log \mathrm{CFU} / \mathrm{g} ; * *$ expressed as presence or absence.

\subsection{Contamination Salmonella spp.}

Results for the detection of Salmonella spp. were shown in Table 3. About $28.5 \%$ of local beef was found to be contaminated by Salmonella spp. while $20.8 \%$ of imported beef samples were positive with this microorganism. This results also showed that their presence in these samples have violated the standard limits by the International Guidelines. Based on the statistical analysis, this study found that there were no significant differences $(p>0.05)$ in microbial counts between the local and imported beef samples for all microbiological parameters.

Table 3. Frequency of Salmonella isolated from local and imported beef samples sold at wet markets in Selangor and Kuala Lumpur

\begin{tabular}{lll}
\hline Samples & No. of samples (n) & No. $(\%)$ positive with Salmonella \\
\hline Local beef & 21 & $6(28.5 \%)$ \\
Imported beef & 24 & $5(20.8 \%)$ \\
\hline Total & $\mathbf{4 5}$ & $\mathbf{1 1}(\mathbf{2 4 . 4 \% )}$ \\
\hline
\end{tabular}




\section{Discussion}

Beef products are easily contaminated with microorganisms due to its nutritious nature and conducive characteristics that favors bacterial growth (Lücke, 2000). Evaluation of the microbiological quality and safety of beef products are commonly carried out by determination of indicator microorganisms' levels such as total viable counts, Enterobacteriaceae and E. coli (Moore et al., 2002; EFSA, 2010). The high levels of bacterial counts and also the presence of Enterobacteriaceae in all samples in this study, suggests that there was a high possibility of fecal contamination occurrence on the beef samples and reflects poor general hygiene status of the wet markets. Other than implying that the shelf life of the tested samples was reduced or even unfit to be consumed (Bhandare et al., 2007; Hassan et al., 2010; Ahmad et al., 2013), the high levels of these indicator microorganisms could also indicates the presence of pathogens, for example pathogenic E. coli and Salmonella spp. (Brown et al., 2000).

To date, there are no microbiological standards specifically for retail raw beef available in Malaysia. Therefore, this study refers to the standards used by Australia and the European Union to interpret the microbiological counts obtained for all parameters. Based on the results obtained, the beef sold at the wet markets in Selangor and Kuala Lumpur falls under the marginal category hence its quality can be deemed as low. Besides poor quality the beef also posed a high risk to the consumers especially if it is not cook properly before consumption. According to the standards, food samples that falls under this category requires corrective actions to be taken such as reviewing the current hygiene level of the beef processing area, training of meat handlers and conduct follow up monitoring to ensure that corrective actions taken are effective (Australian Standards, 2002; EU, 2002).

Presence of Salmonella spp. were detected in some of the samples in this study. Australian Standards (2002) has set a zero tolerance policy of Salmonella in any retail beef samples as this bacteria is a food-borne disease causing pathogen. Previous study from Stevens et al. (2008), showed that incidence of Salmonella sp. on retail beef was higher than on beef samples from the abattoir, suggesting that contamination of this bacteria on retail beef might be mainly due to cross-contamination by the meat handlers at the market or during transportation rather than during slaughter and processing in the abattoir. This study also found presence of E. coli $\mathrm{O} 157: \mathrm{H} 7$, an enteric pathogen on the beef samples tested. A study by Radu et al. (1998) which was conducted in Malaysia, had also found E. coli $\mathrm{O} 157: \mathrm{H} 7$ in $36 \%$ of their tested beef samples. Although there was no E. coli O157:H7 outbreak has been reported here in Malaysia, the incidence of food-borne disease caused by this pathogen has been highly reported in countries such as United States and also United Kingdom (Rangel et al., 2005; Locking et al., 2015). Ingestion of E. coli $\mathrm{O} 157: \mathrm{H} 7$ is highly dangerous due to its low infectious dose (Desmarchelier \& Fegan, 2003) which would lead to hemorrhagic diarrhea or worse, hemolytic uremic syndrome (HUS) and eventually death to the infected person (Karmali et al., 1983).

The initial contamination of beef products usually occurred during the slaughter and processing in the abattoir. However, in this study, there were no significant differences found in the level of bacterial contamination between local and imported beef. Previous study from Stevens et al. (2008), showed that incidence of Salmonella spp. on retail beef was higher than on beef samples from the abattoir, suggesting that contamination of this pathogen or other microorganisms on retail beef might be mainly occurred during transportation or due to cross-contamination by the meat handlers at the market rather than during slaughter and processing in the abattoir. This also strengthen the need to maintain a safe food chain as the safety of the beef products can still be compromised along every step of its production.

Various factors could contribute to the increase of bacterial contamination on beef products in wet markets (Sofos, 2008). One of the main contributing factors is temperature where long exposure to unsafe temperature will increase the growth of microorganism on the beef products (Koutsoumanis \& Taokis, 2005). According to Rhodes et al. (2009), climate could also contribute to the increase of bacterial contamination in beef as the combination of high temperatures and high humidity throughout the year such as in Malaysia is highly favourable for bacterial growth. The open-air design of the wet markets where appropriate temperature control was not well equipped or even non-existing further increase the risk of temperature abuses as compared to closed building supermarkets or hypermarkets that are more equipped with proper storage facilities with adequate temperature control for their meat. Based on the observation from this study, most beef vendors in the wet markets display their meat products on the open-air retail counter from early morning until closing in the late afternoon, causing the beef products to be exposed to ambient temperature and environment for a long period of time. 
Microbial contamination of beef products can also due to the poor sanitary knowledge and practices among the meat handler (Tan et al., 2008). Microorganisms can easily be transferred from the hands of the meat handlers to the beef products. Meat handlers who did not clean their hands thoroughly after visiting the toilet can contaminate their hands with enteric bacteria that then can be transferred to the beef (Taylor et al., 2000; Barza, 2004). Usage of gloves could help in reducing this source of contamination but care must be taken by the meat handlers to change or sanitize their gloves from time to time as the bacteria can accumulate on the glove surface (Lues et al., 2005).

Besides that, contamination could also occur through cross contamination from meat contact surfaces as bacteria may accumulate on the handling tools or equipment and then can be transferred to the beef (Van Asselt et al., 2008). In previous study, cutting and mincing process of retail beef with dirty equipment had shown a significant increase of microbial loads on the minced beef surface as compared to that in whole carcasses (Fenlon et al., 2008). Foodborne pathogens from contaminated meats that transferred to such surfaces can spread infections to the consumers especially if it is not cooked thoroughly (Gorman et al., 2002). The hygiene status of the retail store including the equipment or surfaces used to handle the meat products need to be maintained to prevent continuous contamination of this commodity.

\section{Conclusions}

In conclusion, this study showed that the quality of beef sold in wet markets around Selangor and Kuala Lumpur are low when compared to the international standard which would increase the safety risk of consumption of this product. Continuous monitoring of this food product as well as the application of hygiene practices along the process from the processing in the abattoir to the retail should be done without fail to ensure the safety of beef supply in Malaysia.

\section{References}

Ahmad, S., Ahsan-ul-Haq, Yousaf, M., Kamran, Z., Ata-ur-Rehman, Sohail, M. U., \& Shahidur-ur-Rahman. (2013). Effect of feeding whole linseed as a source of polyunsaturated fatty acids on performance and egg characteristics of laying hens kept at high ambient temperature. Brazilian Journal of Poultry Science, 15(1), 21-25. https://doi.org/10.1590/S1516-635X2013000100004

Anjum, Q., Omair, A., Ahmed, Y., Shaikh, S., Usman, J., \& Qureshi, F. (2004). Frequency of Food Items among Households in a Low Socioeconomic Area of Karachi. Journal of the Pakistan Medical Association, 54, 580-582.

Australian Standard. (2002). Meat Standards Committee Microbiological testing for process monitoring in the meat industry guideline. Retrieved from https://www.primesafe.vic.gov.au/uploads/Victorian\%20Standards/ Microbiological\%20Guidelines_Meat.pdf

Barza, M. (2004). Efficacy and tolerability of C1O2-generating gloves. Clinical Infectious Diseases, 38, 857-863. https://doi.org/10.1086/382535

Bhandare, S. G., Sherikarv, A. T., Paturkar, A. M., Waskar, V. S., \& Zende, R. J. (2007). A comparison of microbial contamination on sheep/goat carcasses in a modern Indian abattoir and traditional meat shops. Food Control, 18, 854-868. https://doi.org/10.1016/j.foodcont.2006.04.012

Brown, M. H., Gill, C. O., Hollingsworth, J., Nickelson, R., Seward, S., \& Sheridan, J. J. (2000). The role of microbiological testing in systems for assuring the safety of beef. International Journal of Food Microbiology, 62, 7-16. https://doi.org/10.1016/S0168-1605(00)00408-6

Chamhuri, N., \& Batt, P.J. (2009). Factors influencing consumers' choice of retail stores for fresh meat in Malaysia. Acta Horticulturae, 831, 237-245. https://doi.org/10.17660/ActaHortic.2009.831.27

Chapman, P. A., Cerdan Malo, A. T., Ellin, M., Ashton, R., \& Harkin, M. A. (1997). Escherichia coli O157 in cattle and sheep at slaughter, on beef and lamb carcasses and in raw beef and lamb products in South Yorkshire, UK. International Journal of Food Microbiology, 64, 139-150. https://doi.org/10.1016/ S0168-1605(00)00453-0

Desmarchelier, P., Fegan, N., Smale, N., \& Small A. (2007). Managing safety and quality through the red meat chain. Meat Science, 77, 28-35. https://doi.org/10.1016/j.meatsci.2007.04.027

EFSA. (2010). The assessment of the comparison of the Australian monitoring programme for carcasses to requirements in Regulation (EC) No. 2073/2005 on microbiological criteria on foodstuffs. European Food Safety Authority Journal, 8, 1452-1503. https://doi.org/10.2903/j.efsa.2010.1452 
European Union. (2002). European Official Journal of European Communities: Food law regulations (EC) No. 178/2002. Retrieved from https://www.fsai.ie/uploadedFiles/Legislation/Food_Legisation_Links/General_ Principles_of_Food_Law/Reg178_2002.pdf

Fratamico, P. M., Bhunia, A. K., \& Smith, J. L. (2005). Foodborne pathogens in Microbiology and Molecular Biology (pp. 270-275). Caister Academic press, Wymondham Norfolk, UK.

Hassan, A. N., Farooqui, A., Khan, A., Khan, A. Y., \& Kazmi, S. U. (2010). Microbial contamination of raw meat and its environment in retail shops in Karachi, Pakistan. Journal of Infection in Developing Countries, 4(6), 382-388.

Karmali, M., Petric, M., Steele, B., \& Lim, C. (1983). Sporadic cases of haemolytic-uraemic syndrome associated with faecal cytotoxin and cytotoxin-producing Escherichia coli in stools. The Lancet, 1(8325), 619-620. https://doi.org/0.1016/S0140-6736(83)91795-6

Koutsoumanis, K. P., \& Taoukis, P. (2005). Improving the Safety of Fresh Meat. In J. S. Sofos (Ed.), Meat safety, refrigerated storage and transport: Modeling and management (pp. 503-561). Woodhead Publishing Ltd., Cambridge, UK.

Locking, M. E., Pollock, K. G., Allison, L. J., Rae, L., Hanson, M. F., \& Cowden, J. M. (2011). Escherichia coli O157 infection and secondary spread, Scotland, 1999-2008. Emerging Infectious Diseases, 17(3), 524-527. https://doi.org/10.3201/eid1703.100167

Lücke, F. K. (2000). Utilization of microbes to process and preserve meat. Meat Science, 56(2), $105-115$. https://doi.org/10.1016/S0309-1740(00)00029-2

Lues, J. F. R., \& Van Tonder, I. (2007). The occurrence of indicator bacteria on hands and aprons of food handlers in the delicatessen sections of a retail group. Food Control, 18(4), 326-332. https://doi.org/ 10.1016/j.foodcont.2005.10.010

Ministry of Agriculture and Agro-Based Industry. (2014). Press statement. Imported beef from India. Malaysia.

Moore, G., \& Griffith, C. (2002). A comparison of surface sampling methods for detecting coliforms on food contact surfaces. Food Microbiology, 19(1), 65-73. https://doi.org/10.1006/fmic.2001.0464

Radu, S., Mutalib, S. A., Rusul, G., Ahmad, Z., Morigaki, T., Asai, N., ... Nishibuchi, M. (1998). Detection of Escherichia coli O157:H7 in the beef marketed in Malaysia. Applied and Environmental Microbiology, 64, 1153-1156.

Rangel, J. M., Sparling, P. H., Crowe, C., Griffin, P. M., \& Swerdlow, D. L. (2005). Epidemiology of Escherichia coli O157:H7 outbreaks, United States, 1982-2002. Emerging Infectious Diseases, 11(4), 603-609. https://doi.org/10.3201/eid1104.040739

Serin, T., Alias, R., Mad Nasir, S., \& Zainalabidin, M. (2008). The efficiency of beef cattle production: A case study in the target area of concentration in Johor, Malaysia. Economic and Technology Management Review, $3,57-54$.

Sofos, J. N. (2008). Challenges to meat safety in the 21st century. Meat Science, 78, 3-13. https://doi.org/ 10.1016/j.meatsci.2007.07.027

Stevens, A., Kabore, Y., Perrier-Gros-Claude, J. D., Millemann, Y., Brisabois, A., Catteau, M., ... Dufour, B. (2006). Prevalence and antibiotic-resistance of Salmonella isolated from beef sampled from the slaughterhouse and from retailers in Dakar (Senegal). International Journal of Food Microbiology, 110(2), 178-186. https://doi.org/10.1016/j.ijfoodmicro.2006.04.018

Tan, Y., Chai, L. C., Mohamad Ghazali, F., Radu, S., \& Haresh, K. K. (2008). Prevalence of Campylobacter spp. In retailed ready-to-eat sushi. International Food Research Journal, 15(3), 331-336.

Taylor, J. H., Brown, K. L., Toivenen, J., \& Holah, J. T. (2000). A microbiological evaluation of warm air hand driers with respect to hand hygiene and the washroom environment. Journal of Applied Microbiology, 89, 910-919. https://doi.org/10.1046/j.1365-2672.2000.01122.x

Todd, E. C. D., Guzewich, J. J., \& Bryan, F. L. (1997). Surveillance of Foodborne Disease IV. Dissemination and Uses of Surveillance Data. Journal of Food Protection, 60(6), 715-723. https://oi.org/10.4315/ 0362-028X-60.6.715 
Van Asselt, E. D., De Jong, A. E. I., De Jonge, R., \& Nauta, M. J. (2008). Cross-contamination in the kitchen: Estimation of transfer rates for cutting boards, hands and knives. Journal of Applied Microbiology, 105(5), 1392-1401. https://doi.org/10.1111/j.1365-2672.2008.03875.x

\section{Copyrights}

Copyright for this article is retained by the author(s), with first publication rights granted to the journal.

This is an open-access article distributed under the terms and conditions of the Creative Commons Attribution license (http://creativecommons.org/licenses/by/4.0/). 